\title{
Oleaginous yeasts for sustainable lipid production-from biodiesel to surf boards, a wide range of "green" applications
}

\author{
Bruno Vasconcelos ${ }^{1}$ (D) $\cdot$ José Carlos Teixeira ${ }^{2} \cdot$ Giuliano Dragone $^{3} \cdot$ José António Teixeira $^{1}$
}

Received: 18 December 2018 / Revised: 3 March 2019 / Accepted: 5 March 2019/Published online: 25 March 2019

(C) Springer-Verlag GmbH Germany, part of Springer Nature 2019

\begin{abstract}
A growing world population and a growing number of applications for vegetable oils are generating an increasing demand for these oils, causing serious environmental problems. A sustainable lipid production is then fundamental to address these problems. Oleaginous yeasts are a promising solution for sustainable lipid production, but, with the current knowledge and technology, they are still not a serious alternative in the market. In this review, the potential of these yeasts is highlighted and a discussion is made mainly focused on the economics of the oleaginous yeast oil production and identification of the key points to be improved to achieve lower production costs and higher income. Three main stages of the production process, where costs are higher, were identified. To render economically feasible the production of oils using oleaginous yeasts, a reduction in production costs must occur in all stages, lipid yields and productivities must be improved, and production must be targeted to high-value product applications.
\end{abstract}

Keywords Oleaginous yeasts $\cdot$ Vegetable oils $\cdot$ Sustainability $\cdot$ Biodiesel $\cdot$ Lipids

\section{Introduction}

The global demand for vegetable oils has been growing every year and is expected to keep growing not only because of the population growth that raises the need of vegetable oils for food applications but also because of the growing number of applications for the vegetable oils, like its application for biofuels, food additives, biopolymers, and pharmaceutical and cosmetic industries. Its use for the production of biodiesel is the application that has promoted the biggest increase on the demand for vegetable oil due to the search for cleaner fuels to reduce greenhouse gas emissions to fight global warming, but that raised many concerns related with the sustainable use of food crops (Anuar and Zuhairi 2016). Like biodiesel, also several of the other applications of the vegetable oils have

Bruno Vasconcelos

brunov@ceb.uminho.pt

1 Centre of Biological Engineering, University of Minho, Braga, Portugal

2 Mechanical Engineering Department, University of Minho, Guimarães, Portugal

3 Novo Nordisk Foundation Center for Biosustainability, Technical University of Denmark, Kongens Lyngby, Denmark environmental concerns associated, as there is a growing demand for greener bio-based alternatives to petrochemicals and others. This increasing demand creates a lot of pressure for expanding crops fields, promoting bigger destruction of forests and raising the water usage, creating serious environmental problems. In this way, what is supposed to be an environmental positive solution like biodiesel and green bio-based products can be a big problem unless we find sustainable ways to produce vegetable or vegetable-like oils. Furthermore, according to the United Nations, the world population is expected to reach 8.6 billion in 2030 and 9.8 billion in 2050, which raises big concerns about food and water resources. To overcome that problem, a raw material production that requires smaller amount of land and water to obtain high productivities must be developed. Oleaginous microorganisms (OM), which can produce oils similar to vegetable oils, have been presented as a possible solution since they have higher growth rate and oil productivity, are easier to cultivate, and use less land and water (Gerbens-Leenes et al. 2009; Yang et al. 2011). Many studies have been conducted with microalgae, yeasts, molds, and bacteria to access their potential. Oleaginous yeasts (OY) are one of the most promising $\mathrm{OM}$ for the production of oils similar to vegetable oils (Qin et al. 2017), since they can accumulate up to more than $70 \%$ lipids in their composition (Ratledge 1991) and exhibit several advantages for lipid production over other sources. Those advantages are related to 
their rapid growth, the requirement for smaller areas for their cultivation, and the fact of being much less affected by climatic conditions than other production systems (Ageitos et al. 2011). Oleaginous yeasts were intensively studied in Germany during World War I and II due to the need on finding ways for internal food, feed, and fuel production (Sitepu et al. 2014). Those studies were of major importance to the research in this area, showing the potential of these yeasts for lipid production. After the Second World War, the researches in this area have diminished. In the last decades, due to the growing interest in biodiesel, oleaginous yeasts got again the attention of the researchers in order to find a sustainable way of producing vegetable oil equivalents for biodiesel and other applications. However, its industrial production is still not feasible because it is not cost-competitive with the current technology (Probst et al. 2017) (Whiffin et al. 2016), although there are studies pointing to cost-competitiveness in particular cases (Park et al. 2017) (Ricardo et al. 2017).

In this paper, the main research that has been done aiming to increase productivity and decrease production costs of oils with OY is reviewed, the potential of the most promising OY is highlighted, and the main hurdles to overcome to turn OY oil production to be cost-competitive are discussed together with the potential applications of these oils. It is a more practical review in this area, more focused on the economics of lipid production and on the identification of the main points to improve towards a competitive vegetable oil equivalent production. Furthermore, since different authors present the results in different units, or just show the results in lipid percentage and lipid yield, in this review, we present the best results obtained to date in terms of lipid productivity and lipid coefficient, which are the units that give a real idea of its potential to become cost-competitive. That way, we can better relate the recent developments to the real impact in the economics of oleaginous microorganism oil production.

\section{Potential of the main oleaginous yeasts}

From the more than 600 yeast species known, fewer than 30 are known to accumulate more than $20 \%$ of their biomass as intracellular lipids (Sargeant et al. 2014). Yeasts that are able to accumulate more than $20 \%$ are designated as oleaginous yeasts. Most of the more promising yeasts are from the genera Yarrowia, Candida, Rhodotorula, Rhodosporidium, Cryptococcus, Trichosporon, and Lipomyces (Ageitos et al. 2011). From those genera, the most studied species for lipid production have been Yarrowia lipolytica, Rhodotorula glutinis, Rhodosporidium toruloides, Cryptococcus curvatus, and Lipomyces starkeyi, although high productivities have been obtained with other species also, like with Trichosporon fermentans (Zhu et al. 2008; Huang et al. 2009, 2012, 2014).

\section{Oleaginous yeast lipid profile}

The oils produced by the main oleaginous yeasts have a lipid profile similar to that of some vegetable oils (Table 1). Fatty acid profiles have been shown to be quite consistent within a species if grown under consistent conditions but can change depending on the culture conditions and the time of cultivation, inducing the obtainment of different lipid profiles for the same yeast in different studies (Sitepu et al. 2013). OY lipid profile is characterized by a predominance of oleic acid but can be changed not only by manipulating culture conditions but also by using selective inhibitors or genetically manipulating the yeasts in order to obtain lipid profiles for the desired application (Sargeant et al. 2014).

\section{Carbon sources, productivity, cultivation methods, and lipid yields}

Oleaginous yeasts are able to utilize a wide range of carbon sources and were successfully cultivated using low-cost carbon sources in different media mainly composed by wastes and/or wastewaters. High productivities and lipid yields were obtained using different low-cost carbon sources and simple cultivation methods. For a better understanding of the order of magnitude of the productivities that can be achieved with oleaginous yeasts, it can be pointed out that the productivity obtained by Ricardo et al. (2017) $(0.44 \mathrm{~g} / \mathrm{L} / \mathrm{h})$ using sugarcane juice as carbon source for the cultivation of the yeast Rhodosporidium toruloides to produce microbial oil for biodiesel production resulted in a biodiesel yield (L/ha of land) 6.3 times bigger than the yield of standard biodiesel from soybean oil (microbial biodiesel $4172 \mathrm{~L} / \mathrm{ha}$ of cultivated sugarcane; soy biodiesel $661 \mathrm{~L} / \mathrm{ha}$ of cultivated soybean). Productivities as high as $1.6 \mathrm{~g} / \mathrm{L} / \mathrm{h}$ were achieved using Lipomyces starkeyi (Lin et al. 2011), and lipid yields reaching up to $0.29 \mathrm{~g}$ of lipid per gram of carbon substrate using Rhodosporidium toruloides (Fei et al. 2016) or Cryptococcus curvatus (Ykema et al. 1988) were already obtained and can further be improved considering that theoretical lipid yields can reach $0.35 \mathrm{gl} / \mathrm{gs}$ and cultivation methods can be improved. Since oleaginous yeasts can obtain high productivities using wastes, wastewaters, or lignocellulosic hydrolysates, there is no competition with food production and there is no need to destroy more forests to grow more crop fields. Also, with the ability of using such a wide range of different carbon sources, the simple cultivation methods, and the fact that there is no need for light to grow them allow for their cultivation anywhere in the world.

Like previously mentioned, the yeasts Rhodotorula glutinis, Yarrowia lipolytica, Rhodosporidium toruloides, Cryptococcus curvatus, and Lipomyces starkeyi were the most studied, and, with each one, different carbon 
Table 1 Relative mass percentage of the main fatty acids present in some seed oils and single-cell oils

\begin{tabular}{llllllll}
\hline & C16:0 & C16:1 & C18:0 & C18:1 & C18:2 & C18:3 & References \\
\hline Rapeseed oil & 3 & - & 1 & 64 & 22 & 8 & Fassinou et al. (2010) \\
Soya oil & 12 & - & 3 & 23 & 55 & 6 & Fassinou et al. (2010) \\
Sunflower oil & 6.40 & 0.01 & 2.90 & 17.70 & 72.90 & - & Fassinou et al. (2010) \\
Jatropha oil & 14.70 & 0.65 & 6.75 & 40.05 & 36.60 & 0.15 & Fassinou et al. (2010) \\
Cocoa butter & 23.31 & 0.95 & 24.51 & 28.74 & 3.93 & - & El-Saied et al. (1981) \\
Palm oil & 43.03 & 0.19 & 4.31 & 39.47 & 10.82 & 0.29 & Fassinou et al. (2010) \\
Cryptococcus curvatus & 18 & - & 16 & 50 & 16 & - & Meesters et al. (1996) \\
Yarrowia lipolytica & 15 & 2 & 11 & 47 & 21 & 3 & Papanikolaou and Aggelis (2002) \\
Rhodosporidium toruloides & 20 & 1 & 15 & 47 & 13 & 3 & Li et al. (2007)) \\
Rhodosporidium toruloides 68-264 & 12 & 0.4 & 20.9 & 54.2 & 5.6 & 1 & Sitepu et al. (2013) \\
Cryptococcus victoriae 10-939 & 21 & 5.5 & 20.5 & 42.5 & 6.6 & 0.8 & Sitepu et al. (2013) \\
Lipomyces starkeyi & 37 & 4 & 6 & 49 & 1 & - & Zhao et al. (2008) \\
Rhodotorula glutinis & 23.80 & 5.90 & 2.00 & 54.80 & 10.70 & 1.70 & Vieira et al. (2014) \\
\hline
\end{tabular}

sources were tested and different productivities and lipid yields were obtained.

With Rhodotorula glutinis (Table 2), the highest productivity obtained was $1.028 \mathrm{~g} / \mathrm{L} / \mathrm{h}$ using glucose as carbon source and a fed-batch cultivation method (Pan et al. 1986). Good productivities were also obtained using cheap carbon sources, like molasses $(0.24 \mathrm{~g} / \mathrm{L} / \mathrm{h})$ (Alvarez et al. 1992) or undetoxified corncob hydrolysate $(0.168 \mathrm{~g} / \mathrm{L} / \mathrm{h})$ (Liu et al. 2015). The highest lipid yield obtained with Rhodotorula glutinis was $0.182 \mathrm{gl} / \mathrm{gs}$, still significantly lower than the theoretical maximum (Johnson et al. 1995).
With the yeast Yarrowia lipolytica (Table 3), the highest productivity obtained was $1.2 \mathrm{~g} / \mathrm{L} / \mathrm{h}$ using glucose as carbon source and a fed-batch cultivation method (Qiao et al. 2017). Good productivities were obtained using cheap carbon sources, like acetic acid $(0.8 \mathrm{~g} / \mathrm{L} / \mathrm{h})(X u$ et al. 2017) or glycerol with volatile fatty acids $(0.330 \mathrm{~g} / \mathrm{L} / \mathrm{h})$ (Fontanille et al. 2012). The highest lipid yield obtained with Yarrowia lipolytica was $0.27 \mathrm{gl} / \mathrm{gs}$ (Qiao et al. 2017).

Using Rhodosporidium toruloides (Table 4), the highest productivity was obtained by a fed-batch cultivation method utilizing glucose as carbon source. Also, good productivities

Table 2 Productivities for Rhodotorula glutinis using different media and different cultivation methods

\begin{tabular}{|c|c|c|c|c|}
\hline Yeasts & Medium & Cultivation method & $\begin{array}{l}\text { Productivity } \\
(\mathrm{g} / \mathrm{L} / \mathrm{h})^{\mathrm{a}}\end{array}$ & References \\
\hline Rhodotorula glutinis & Glycerol + yeast extract & Fed-batch & 0.030 & Karamerou et al. (2016) \\
\hline Rhodotorula glutinis & Potato wastewater + glycerol & Batch in flask & 0.031 & Kot et al. (2017) \\
\hline Rhodotorula glutinis & $\begin{array}{l}\text { P. euramevicana leaves hydrolysates + yeast } \\
\text { extract + peptone }\end{array}$ & Airlift Bioreactor & 0.066 & Dai et al. (2007)) \\
\hline Rhodotorula glutinis & Crude glycerol + thin stillage & Fed-batch & 0.066 & Yen et al. (2012)) \\
\hline Rhodotorula glutinis & Monosodium glutamate wastewater + glucose & Fed-batch & 0.070 & Xue et al. (2008) \\
\hline Rhodotorula glutinis & Crude glycerol $+\left(\mathrm{NH}_{4}\right)_{2} \mathrm{SO}_{4}+$ Tween 20 & Fed-batch & 0.084 & Saenge et al. (2011) \\
\hline Rhodotorula glutinis & Hydrolyzed pineapple pulp residue $+\left(\mathrm{NH}_{4}\right)_{2} \mathrm{SO}_{4}$ & Batch in flask & 0.100 & Tinoi and Rakariyatham (2016) \\
\hline Rhodotorula glutinis & Molasses + glucose & Fed-Batch & 0.120 & Johnson et al. (1995) \\
\hline Rhodotorula glutinis & Undetoxified corncob hydrolysate $+\left(\mathrm{NH}_{4}\right)_{2} \mathrm{SO}_{4}$ & Fed-Batch & 0.168 & Liu et al. (2015) \\
\hline Rhodotorula glutinis & Molasses $+\left(\mathrm{NH}_{4}\right)_{2} \mathrm{SO}_{4}+\left(\mathrm{NH}_{4}\right)_{2} \mathrm{HPO}_{4}$ & Continuous & 0.240 & Alvarez et al. (1992) \\
\hline Rhodotorula glutinis & $\begin{array}{l}\text { Sucrose; }\left(\mathrm{NH}_{4}\right)_{2} \mathrm{SO}_{4} ; \mathrm{MgCl}_{2} \times 6 \mathrm{H}_{2} \mathrm{O} ; \mathrm{CaCl}_{2} \times 2 \mathrm{H}_{2} \mathrm{O} \\
\quad \mathrm{MgSO}_{4} \times 7 \mathrm{H}_{2} \mathrm{O} ; \text { myo-inositol; } \mathrm{KH}_{2} \mathrm{PO}_{4} ; \mathrm{K}_{2} \mathrm{HPO}_{4} \\
\text { trace elements solution and vitamin solution }\end{array}$ & Fed-batch & 0.795 & Lorenz et al. (2017) \\
\hline Rhodotorula glutinis & $\begin{array}{l}\text { Glucose; } \mathrm{KH}_{2} \mathrm{P} 04 ; \mathrm{Na}_{2} \mathrm{HPO}_{4} ;\left(\mathrm{NH}_{4}\right)_{2} \mathrm{SO}_{4} ; \mathrm{MgSO}_{4} .7 \mathrm{H}_{2} 0 \\
\quad \mathrm{CaCl}_{2} .2 \mathrm{H}_{2} \mathrm{O} \text {; yeast extract }\end{array}$ & Fed-batch & 1.028 & Pan et al. (1986) \\
\hline
\end{tabular}

${ }^{\mathrm{a}}$ Calculated based on references 
Table 3 Productivities obtained by Yarrowia lipolytica using different media and different cultivation methods

\begin{tabular}{|c|c|c|c|c|}
\hline Yeasts & Medium & Cultivation method & $\begin{array}{l}\text { Productivity } \\
(\mathrm{g} / \mathrm{L} / \mathrm{h})^{\mathrm{b}}\end{array}$ & References \\
\hline Yarrowia lipolytica & $\begin{array}{l}\text { Lard + yeast extract }+ \text { Arabic gum }+ \text { potassium } \\
\text { phosphate buffer }\end{array}$ & Batch in flask & 0.055 & Lopes et al. (2018) \\
\hline Yarrowia lipolytica & Glycerol $+\mathrm{YNB}+\left(\mathrm{NH}_{4}\right)_{2} \mathrm{SO}_{4}$ & Batch in flask & 0.066 & Dobrowolski et al. (2016) \\
\hline Yarrowia lipolytica & Sugarcane bagasse hydrolysate + peptone & Batch in flask & 0.073 & Tsigie et al. (2011) \\
\hline Yarrowia lipolytica & Glycerol + minimal medium + olive oil & Batch in flask & 0.102 & Magdouli et al. (2017) \\
\hline Yarrowia lipolytica & $\begin{array}{l}\text { Crude glycerol; } \mathrm{KH}_{2} \mathrm{PO}_{4} ; \mathrm{Na}_{2} \mathrm{HPO}_{4} ; \mathrm{MgCl}_{2} \cdot 6 \mathrm{H}_{2} \mathrm{O} \\
\mathrm{CaCl}_{2} ; \mathrm{FeCl}_{3} \cdot 6 \mathrm{H}_{2} \mathrm{O} ; \mathrm{ZnSO}_{4} \cdot 7 \mathrm{H}_{2} \mathrm{O} ; \mathrm{MnSO}_{4} \cdot \mathrm{H}_{2} \mathrm{O} \\
\mathrm{MgSO}_{4} \cdot 7 \mathrm{H}_{2} \mathrm{O} ;\left(\mathrm{NH}_{4}\right)_{2} \mathrm{SO}_{4} ; \text { yeast extract }\end{array}$ & Continuous & 0.120 & Papanikolaou and Aggelis (2002) \\
\hline Yarrowia lipolytica & Crude glycerol $+\mathrm{NH}_{4} \mathrm{OH}$ & Fed-batch & 0.199 & Sara et al. (2016) \\
\hline Yarrowia lipolytica & Glycerol + volatile fatty acids $+\left(\mathrm{NH}_{4}\right)_{2} \mathrm{SO}_{4}$ & Fed-batch & 0.330 & Fontanille et al. (2012) \\
\hline Yarrowia lipolytica & $\begin{array}{l}\text { Acetic acid }+ \text { ammonium sulfate }+ \text { sodium } \\
\text { acetate }+ \text { yeast extract }+ \text { YNB }+ \text { acetate }\end{array}$ & $\begin{array}{l}\text { Semi-continuous } \\
\text { fermentation system }\end{array}$ & 0.8 & Xu et al. (2017) \\
\hline Yarrowia lipolytica $^{\mathrm{b}}$ & Glucose $+\mathrm{YNB}+\left(\mathrm{NH}_{4}\right)_{2} \mathrm{SO}_{4}$ & Fed-batch & 1.2 & Qiao et al. (2017) \\
\hline
\end{tabular}

${ }^{a}$ Engineered strain

${ }^{\mathrm{b}}$ Calculated based on references

were obtained using cheap carbon sources, like sugarcane juice $(0.44 \mathrm{~g} / \mathrm{L} / \mathrm{h})$ (Ricardo et al. 2017) or corn stove hydrolysate $(0.4 \mathrm{~g} / \mathrm{L} / \mathrm{h})($ Fei et al. 2016). The highest lipid yield obtained with Rhodosporidium toruloides was $0.29 \mathrm{gl} / \mathrm{gs}$ revealing high capability to use lignocellulosic hydrolysates as carbon source (Fei et al. 2016).

For Cryptococcus curvatus (Table 5), the highest productivity was obtained using whey permeate as carbon source (0.995 g/L/h) (Ykema et al. 1988), an even better productivity than the ones obtained using glucose. The cultivation method used was batch partial recycling. Also, with glycerol, better productivities $(0.59 \mathrm{~g} / \mathrm{L} / \mathrm{h})$ (Meesters et al. 1996) than with glucose $(0.47 \mathrm{~g} / \mathrm{L} / \mathrm{h})$ were obtained (Zhang et al. 2011). This yeast is the most versatile in terms of the utilization of different carbon sources, with good productivities being obtained with different carbon sources. The highest lipid yield obtained with Cryptococcus curvatus was $0.29 \mathrm{gl} / \mathrm{gs}$, revealing high capability to use lactose as carbon source (Ykema et al. 1988).

With Lipomyces starkeyi (Table 6), the highest productivity obtained was $1.6 \mathrm{~g} / \mathrm{L} / \mathrm{h}$, the highest of all the five yeasts considered, using glucose as carbon source and a two-stage fermentation cultivation method (Lin et al. 2011). Good productivities were obtained using cheap carbon sources, like hydrolyzed flour-based industrial waste streams $(0.4 \mathrm{~g} / \mathrm{L} / \mathrm{h})$ (Tsakona et al. 2014) or cellobiose and xylose $(0.125 \mathrm{~g} / \mathrm{L} / \mathrm{h})$ (Gong et al. 2012). The highest lipid yield obtained with Lipomyces starkeyi was $0.236 \mathrm{gl} / \mathrm{gs}$ (Anschau et al. 2014).

High productivities can be achieved with all these yeasts, using different low-cost carbon sources. This ability is really important since it allows in each region of the world, to use the

Table 4 Productivities obtained by Rhodosporidium toruloides using different media and different cultivation methods

\begin{tabular}{|c|c|c|c|c|}
\hline Yeasts & Medium & $\begin{array}{l}\text { Cultivation } \\
\text { method }\end{array}$ & $\begin{array}{l}\text { Productivity } \\
(\mathrm{g} / \mathrm{L} / \mathrm{h})^{\mathrm{a}}\end{array}$ & References \\
\hline Rhodosporidium toruloides & Bioethanol wastewater + glucose & Batch in flask & 0.020 & Zhou et al. (2013) \\
\hline Rhodosporidium toruloides & Distillery wastewater + domestic wastewater & Batch in flask & 0.049 & Ling et al. (2013) \\
\hline Rhodosporidium toruloides & $\begin{array}{l}\text { Distillery wastewater }+ \text { domestic } \\
\text { wastewater }+ \text { spent seed culture }\end{array}$ & Batch in flask & 0.057 & Ling et al. (2017) \\
\hline Rhodosporidium toruloides & Crude glycerol + 2-(N-morpholino) ethanesulfonic & Batch in flask & 0.102 & Yang et al. (2014a) \\
\hline Rhodosporidium toruloides & Crude glycerol + solid-state fermentation autolysate & Batch & 0.132 & Uçkun Kiran et al. (2013) \\
\hline Rhodosporidium toruloides & Glucose + yeast extract $+\mathrm{NaNO}_{3}+\mathrm{MgSO}_{4}$ & Fed-batch & 0.260 & Saran et al. (2017) \\
\hline Rhodosporidium toruloides & Jerusalem artichoke extracts & Fed-batch & 0.380 & Zhao et al. (2010) \\
\hline Rhodosporidium toruloides & Corn stove hydrolysate + YNB & Fed-batch & 0.4 & Fei et al. (2016) \\
\hline Rhodosporidium toruloides & Sugarcane juice + urea & Fed-batch & 0.440 & Ricardo et al. (2017) \\
\hline Rhodosporidium toruloides & Glucose + peptone + yeast extract & Fed-batch & 0.540 & Li et al. (2007) \\
\hline
\end{tabular}

${ }^{\mathrm{a}}$ Calculated based on references 


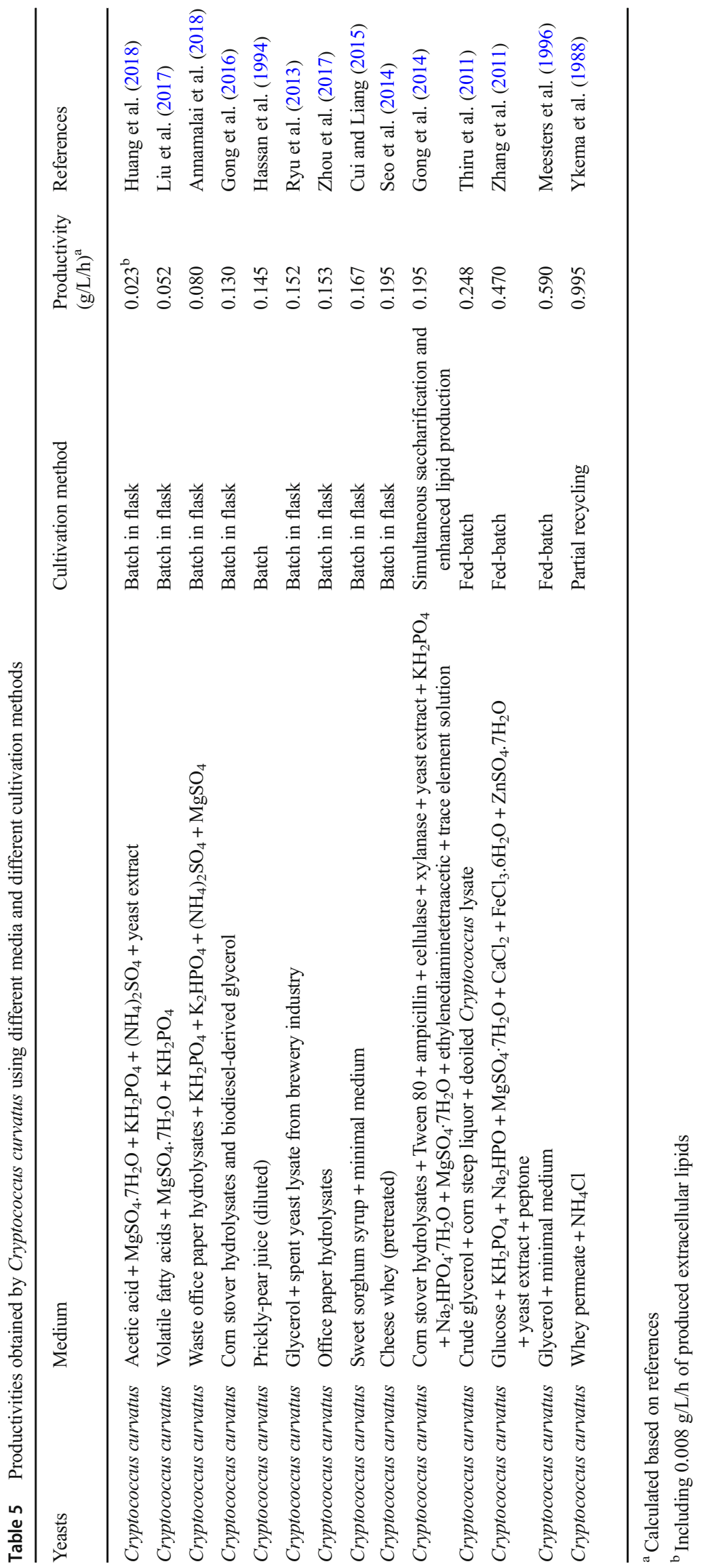




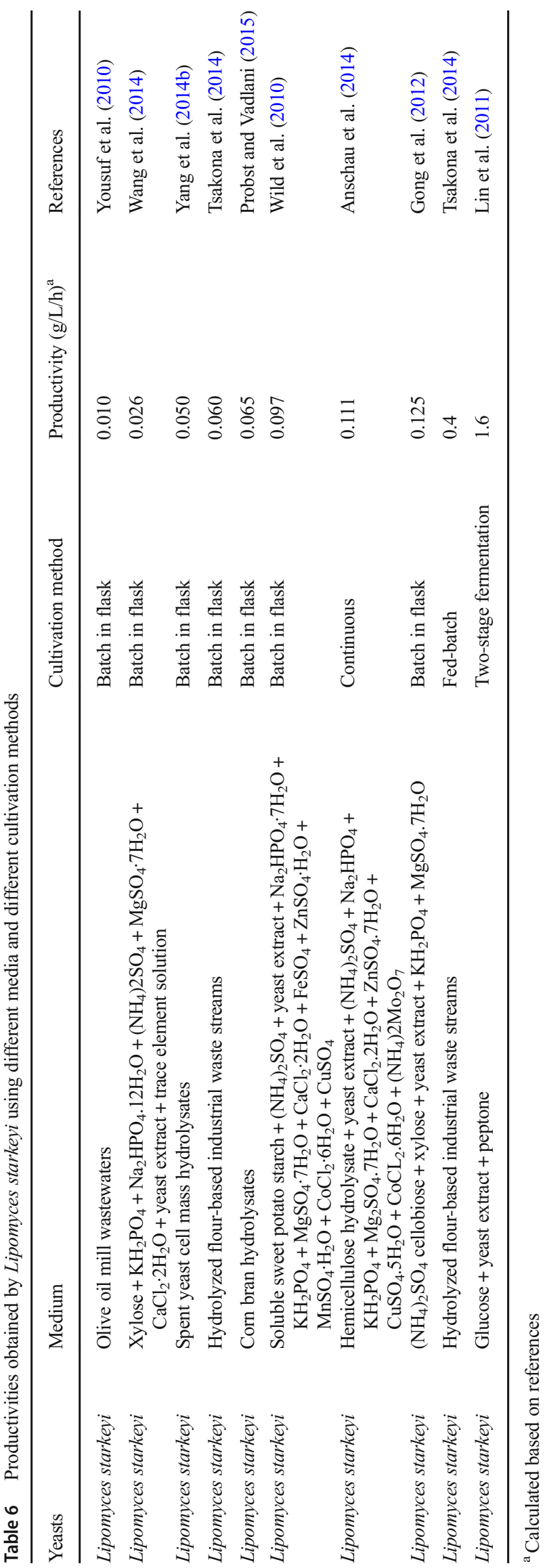

most abundant and cheap local carbon source, using for that the most suitable oleaginous yeast. To choose the most suitable yeast for a certain carbon source, it is also important to know the lipid yields that can be obtained. Different lipid yields were obtained by the oleaginous yeasts using different carbon sources (Table 7). It is important to highlight that, in some cases, lipid yields were close to the theoretical maximum, using low-cost carbon sources.

\section{Production costs}

Only a few studies are available about the economics of yeast oil production, and the results obtained differed significantly according to the different scenarios considered. In some studies, with the current technology, yeast oil production is still considered non cost-competitive, due to the high production costs, making it more expensive than vegetable oils (Koutinas et al. 2014) (Ratledge and Cohen 2008). Koutinas made a techno-economic evaluation of microbial oil (MO) production and subsequent production of biodiesel, using the yeast Rhodosporidium toruloides (Koutinas et al. 2014). They have evaluated four different flowsheets, one for the production of yeast cells, other for the oil extraction and purification, and 2 more for the biodiesel produced either by direct or indirect transesterification of MO. The experimental results obtained by $\mathrm{Li}$ were used for the development of the process flow diagram ( $\mathrm{Li}$ et al. 2007). A productivity of $0.54 \mathrm{~g} / \mathrm{L} / \mathrm{h}$ and an overall glucose to microbial mass and $\mathrm{MO}$ conversion yields of 0.35 and $0.23 \mathrm{~g} / \mathrm{g}$, respectively, were considered in this study. The fermentation was carried out in fed-batch mode and had two stages, one for microbial growth and the other for $\mathrm{MO}$ accumulation. The results were obtained based on an annual production capacity of $10,000 \mathrm{t}$ of microbial oil. Considering the cost of glucose as being zero, an estimated production cost of purified microbial oil of $\$ 3.4 / \mathrm{kg}$ was obtained. Considering a glucose price of $\$ 400 / t$, the price would rise to an estimated cost of $\$ 5.5 / \mathrm{kg}$ oil. Note also that, in this study, yeast extract was used as nitrogen source, at a cost of $\$ 800 / t$ accounting for $16.46 \%$ of the raw material costs while glucose accounts for $79.28 \%$ if considered at a price of $\$ 400 / t$. Besides the evident influence of the feedstock price in the production cost, Koutinas concluded that the main costs are the capital investment and electricity consumption associated with the operation of classical fermenters (Koutinas et al. 2014). The total fixed capital investment for a $10,000 \mathrm{t} \mathrm{MO}$ production plant like this was estimated to be $\mathrm{M} \$ 71.5$, coming more than half of the value from the fermenters.

Other economical study was made in New Zealand using the yeast Cryptococcus curvatum and lactose coming from cheese and butter creameries as carbon source to obtain cocoa butter equivalent (CBE) (Ratledge and Cohen 2008). High yields and conversion ratios of lactose to oil were achieved, 
Table 7 Lipid yields obtained by the oleaginous yeasts using different carbon sources

\begin{tabular}{|c|c|c|c|}
\hline Yeasts & Carbon source & $\mathrm{Y}_{\mathrm{L} / \mathrm{S}}(\mathrm{gl} / \mathrm{gs})$ & References \\
\hline \multirow[t]{4}{*}{ Rhodotorula glutinis } & Glycerol & 0.101 & Karamerou et al. (2016) \\
\hline & Corncob hydrolysate & 0.159 & Liu et al. (2015) \\
\hline & Sucrose & 0.180 & Lorenz et al. (2017) \\
\hline & Glucose & 0.182 & Johnson et al. (1995) \\
\hline \multirow[t]{3}{*}{ Yarrowia lipolytica } & Glycerol & 0.140 & Sara et al. (2016) \\
\hline & Acetic acid & 0.160 & Xu et al. (2017) \\
\hline & Glucose & 0.270 & Qiao et al. (2017) \\
\hline \multirow[t]{4}{*}{ Rhodosporidium toruloides } & Glycerol & 0.220 & Yang et al. (2014a) \\
\hline & Glucose & 0.260 & Li et al. (2007) \\
\hline & Acetic acid & 0.277 & Huang et al. (2016) \\
\hline & Corn stove hydrolysate & 0.290 & Fei et al. (2016) \\
\hline \multirow[t]{7}{*}{ Cryptococcus curvatus } & Corn stove hydrolysates & 0.159 & Gong et al. (2014) \\
\hline & Acetic acid & 0.172 & Liu et al. (2017) \\
\hline & Volatile fatty acids & 0.187 & Liu et al. (2017) \\
\hline & Glycerol & 0.220 & Ryu et al. (2013) \\
\hline & Cardboard hydrolysates & 0.224 & Zhou et al. (2017) \\
\hline & Glucose & 0.246 & Zhang et al. (2011) \\
\hline & Whey permeate & 0.290 & Ykema et al. (1988) \\
\hline \multirow[t]{6}{*}{ Lipomyces starkeyi } & Glycerol & 0.150 & Wang et al. (2014) \\
\hline & Sweet potato starch & 0.160 & Wild et al. (2010) \\
\hline & Glucose & 0.180 & Gong et al. (2012) \\
\hline & Xylose & 0.180 & Gong et al. (2012) \\
\hline & Cellobiose & 0.200 & Gong et al. (2012) \\
\hline & Hemicellulose hydrolysate & 0.236 & Anschau et al. (2014) \\
\hline
\end{tabular}

$\mathrm{Y}_{\mathrm{L} / \mathrm{S}}$, lipid yield $\mathrm{g}_{\mathrm{L}} / \mathrm{g}_{\mathrm{S}}$ (conversion yield of lipid formed per carbon substrate consumed) quality of the oil was entirely satisfactory as a CBE, and manufacturing cost of the yeast oil was calculated as US\$ $800-1000 / \mathrm{t}$ based on using $200,000 \mathrm{~m}^{3}$ of whey/year. This cost did not include plant depreciation, interest on capital investment, or manufacturing overheads. A calculated likely selling price of US\$2000-2500/t was obtained, which would make it cost-competitive if a reduction in the price of cocoa butter had not occurred. At the time the study started, the cost of cocoa butter was about US\$5000/t, but short time after the price dropped $40 \%$, making the production insufficiently profitable to justify further development of the process (Ratledge and Cohen 2008). This study ends up by pointing this process not to be cost-competitive if the cost of cocoa butter keeps low. Anyway, it must be noted that the trend after 2000 was for the prices to increase due to the prevalence of harmful insects and viruses and the general failure of the cultivation techniques of the cocoa plant, being even considered the risk of their disappearing (Papanikolaou and Aggelis 2011).

Park assessed the economics of microbial lipids for biodiesel production using volatile fatty acids (VFAs) derived from organic waste as carbon source and a multistage continuous high cell density culture (MSCHCDC) process (Park et al. 2014). They made a simulation study assuming a lipid yield of $0.3 \mathrm{~g} / \mathrm{g}$ VFAs, cell mass yield of $0.5 \mathrm{~g} / \mathrm{g}$ glucose or wood hydrolysates, and employing process variables including lipid contents from 10 to $90 \%$ of cell mass, bioreactor productivity of $0.5-48 \mathrm{~g} / \mathrm{L} /$ $\mathrm{h}$, and plant capacity of 20,000-1,000,000 metric ton (MT)/year. They estimated, for a 100,000 MT/year production capacity, a production cost of US\$1.048/ $\mathrm{kg}$ lipid, considering carbon source costs of US\$ $0.2 / \mathrm{kg}$ for wood hydrolysates and US\$ $0.15 / \mathrm{kg}$ for VFAs; nitrogen source $\left(\mathrm{NH}_{3}\right)$ US\$ $0.2 / \mathrm{kg}$; water US\$ $0.305 / \mathrm{MT}(904,166$ MT per year); $n$-Hexane US\$ $1.5 / \mathrm{kg}$; bioreactor productivity of $9 \mathrm{~g} / \mathrm{L} / \mathrm{h} ; 100,000 \mathrm{MT} /$ year production capacity; and $75 \%$ lipid content in cell mass. For a more realistic productivity of $1.5 \mathrm{~g} / \mathrm{L} / \mathrm{h}$, close to the maximum productivity obtained with oleaginous yeasts $(1.6 \mathrm{~g} / \mathrm{L} / \mathrm{h}$ obtained by Lin et al. in a two-stage fermentation process with Lipomyces starkeyi (Lin et al. 2011)), the production cost was estimated to be US $\$ 1.422 / \mathrm{kg}$ lipid. In this study, the variables having the highest impact on microbial lipid production costs were the cost of VFAs and lipid yield, followed by lipid productivity, lipid content, and 
fermenter cost. The carbon source (wood hydrolysates + VFAs) and the utilities were the main contributors for the final production cost representing 60.45 and $21.44 \%$ of the production costs, respectively. The total fixed capital investment for a $100,000 \mathrm{t}$ microbial lipid production plant was estimated to be $\mathrm{M} \$ 52.9$. The main contributor for the equipment cost is the fermentation process equipment that represents $41 \%$ of the total equipment cost, followed by the medium preparation equipment $(26.6 \%)$, cell mass washing and recovery $(17.9 \%)$, and lipid extraction $(14.5 \%)$. In this study, despite being a 10 times bigger capacity plant than the one referred in Koutinas et al. (2014), total fixed capital investment is lower, mainly because of the lower price of the fermentation process equipment. Plant capacity has also a big influence in the final production cost, since the smallest plant assessed in this study, with a capacity of 20,000 MT/year, resulted in a production cost of US\$ $1.705 / \mathrm{kg}$ and the largest assessed plant size of 1,000,000 MT per year resulted in a production cost of only US\$ $0.876 / \mathrm{kg}$. The bigger the plant capacity, the more diluted will be the capital investment cost influence in the production cost.

In a more recent study, Park used volatile fatty acids, obtained via anaerobic digestion of rice straw hydrolysates, as carbon source, for microbial lipid production by Cryptococcus curvatus, and the estimated production cost was US\$1.15/L lipid $(1.35 / \mathrm{kg}$ lipid) considering a carbon source cost of US\$ $0.15 / \mathrm{kg}$ (Park et al. 2017). The cost could be as low as US\$ $0.30 / \mathrm{L}(0.35 / \mathrm{kg})$ if the cost of the carbon source is considered equal to zero. In both cases, nitrogen source was considered as having cost zero and the lipid yield was $0.15 \mathrm{~g} / \mathrm{g}$. In South Korea, the overall cost of food waste was estimated to be US\$ $-0.60 / \mathrm{kg}$ VFAs by a local government subsidy. In this study, the overall lipid costs for operational expenses other than the feedstock, including utilities, labor, waste treatment, and facility costs, were assumed to be US\$ $0.354 / \mathrm{kg}$, based on the previously mentioned study of Park et al. (2014).

Fei assessed the effect of volatile fatty acids as a sole carbon source on lipid accumulation by Cryptococcus albidus for biodiesel production and made a preliminary cost analysis of the production of lipids (Fei et al. 2011b). A lipid yield of $0.15 \mathrm{~g} / \mathrm{g}$ of VFAs, a plant production capacity of 1,000,000 ton of lipid per year and a variation of VFAs cost between US\$ -20 per ton and US\$ 100 per ton was considered in that analysis. In those conditions, the production cost of the lipids would range between US\$ 0.16 and $1.055 / \mathrm{kg}$ of lipids. In this analysis, although the capital investment cost, that is one of the main contributors to the final cost according to Koutinas et al. (2014), was not considered, the obtained values are very promising.

Ryu et al. (2013) used the same method as Fei et al. (2011b) to assess the production cost of lipids obtained with Cryptococcus curvatus cultivated on spent yeast from brewery industries and glycerol. They calculated that the lipid production cost would be US\$ $0.292 / \mathrm{kg}$, coming a large part of the cost from the cost of separation of the spent yeast from fermented wastewaters. Like in the study of Fei et al. (2011b), they did not consider the capital investment cost.

Ricardo et al. developed in Brazil a successful pilotscale process for biodiesel production from microbial oil produced by Rhodosporidium toruloides DEBB 5533 (Ricardo et al. 2017) using sugarcane juice as carbon source and urea as nitrogen source. In their study, they were able to reach a lipid productivity of $0.44 \mathrm{~g} / \mathrm{L} / \mathrm{h}$ in a bioreactor of $1000 \mathrm{~L}$ working volume in fed-batch mode. They made a preliminary economic analysis that was based in the costs of the medium and energy involved in each step of the biooil and biodiesel production. They demonstrated microbial biodiesel production economically competitive (US\$ $0.76 / \mathrm{L}$ ) when compared to the vegetable biodiesel (US\$ $0.81 / \mathrm{L}$ ). The price of the carbon source was US\$ $0.14 / \mathrm{kg}$ and the nitrogen source US\$ $0.265 / \mathrm{kg}$. This is a very particular case where the microbial oil obtained is used for biodiesel production in a country where the cost of sugarcane juice is very low. It should also be taken in consideration that in the economic analysis it was assumed that part of the electricity would be provided from an alcohol factory, which generates electricity from the sugarcane bagasse burn. Furthermore, in this preliminary economic analysis, only the costs of the medium and energy involved were considered and, for instance, the capital investment cost was not taken in consideration. Anyway, it remains a very promising result.

These studies allow for the identification of the production stages that have a bigger influence in the final production cost of lipids using OY. Despite that these studies were made mostly in different scenarios, the stages of production where the production costs are higher are the same. We can divide the production process in three main stages in decreasing order of magnitude (Fig. 1): medium preparation, fermentation process, and downstream processing. Medium preparation is the most costly stage, mainly because of the carbon and nitrogen source costs; the fermentation process is the second most costly stage mainly because of the investment cost and energy needed; and the downstream processing is the less costly despite of still having significant cost associated to the cell mass washing and recovery and to lipid extraction.

\section{Main points of improvement to lower production cost and increase incomes}

Many studies have been done with the goal of reducing the production costs. In this section, the main aspects to be considered for cost reduction will be discussed and solutions for process improvement will be identified in each of the stages 


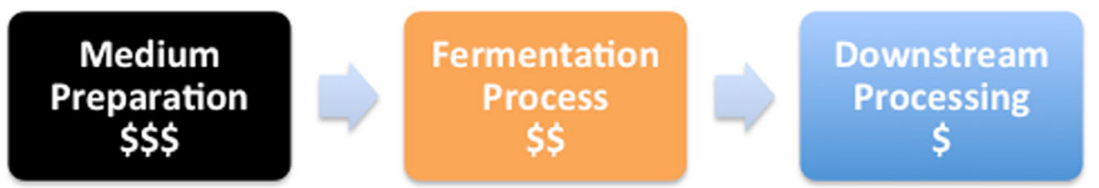

Fig. 1 The three main stages of the production process contributing for the final production cost, in decreasing cost order

mentioned before (medium preparation, fermentation process and downstream processing).

\section{Medium preparation}

As medium preparation is the most costly stage, most of the studies have dealt with this aspect. The main costs in this stage come from the carbon source, the nitrogen source, the sterilization of the medium, and water usage, if a traditional fermentation is going to be carried out.

The main contributor to the final cost is by far the carbon source. Glucose is considered an effective carbon source in the fermentation processes, but if glucose is used as carbon source (\$500/t in 2010), it can represent as much as $80 \%$ of the total medium cost, contributing to over $60 \%$ of the total production costs in a typical fermentation process (Fei et al. 2011a). In lipid production by oleaginous yeasts, it needed a much higher amount of carbon source than nitrogen source, since high carbon-to-nitrogen $(\mathrm{C} / \mathrm{N})$ ratios are favorable to trigger high lipid accumulation and when nitrogen is limiting for the production of biomass, the carbon source can be converted to storage lipid (Ratledge 2002). That is why most of the studies are about finding low-cost carbon sources that can be used as good substitutes of glucose. To be a good substitute, it has to be cheap, abundant, and allow good productivities. Wastes and wastewaters are strong candidates to be used as carbon source since they are abundant and have no cost or represent even negative cost. Oleaginous yeasts can utilize a wide variety of different carbon sources, which allows to explore the possibility of using many different low-cost carbon sources.

\section{Wastewaters}

Oleaginous yeasts can be used with the dual purpose of treating wastewater and producing microbial lipids. Wastewaters can be at the same time carbon and water sources for the oleaginous yeasts besides providing several other nutrients. A few authors tested wastewaters of different kinds. Xue assessed the potential of using diluted monosodium glutamate wastewater as a cheap fermentation broth for Rhodotorula glutinis (Xue et al. 2006). Although, in the initial experiments, a low productivity was obtained, a new study (Xue et al. 2008) was made where diluted monosodium glutamate wastewater was supplemented with glucose to increase the $\mathrm{C} / \mathrm{N}$ ratio. In this case, although glucose is used, the utilization of monosodium glutamate wastewater could contribute to reduce the amount of glucose and water needed for microbial lipid production. Despite a considerable increase in the productivity, the value obtained was still far from the productivities for other media. Bioethanol wastewater was also assessed for its potential as a cheap fermentation broth, with glucose being also used as supplement to increase the productivity (Zhou et al. 2013). Similar results were obtained as the ones previously reported for the use of monosodium glutamate wastewater. In both cases, further studies should be done to increase productivity and find a cheaper supplement than glucose. Better productivities, although still not very high, were obtained with a mixture of distillery wastewater and domestic wastewater without sterilization, using the yeast Rhodosporidium toruloides (Ling et al. 2013). In this case, besides using a low-cost carbon source, they also eliminated the sterilization step. In another study, it was tested with success the possibility to reuse the spent seed culture medium of Rhodosporidium toruloides, and that allowed for a reduction of around 30\% in the medium cost (Ling et al. 2017). Several other wastewaters like olive oil mill wastewaters (Yousuf et al. 2010) and potato wastewaters supplemented with glycerol (Kot et al. 2017) were tested, but low productivities were obtained. Only few wastewaters were tested until now. Many other agro-industrial wastewaters can still be assessed, and the supplementation with other cheap carbon sources can possibly increase the productivities and lipid yields since with some yeasts the productivities and lipid yields were even higher when using cheap carbon sources than using glucose, like as was mentioned in the "Carbon sources, productivity, cultivation methods, and lipid yields" section.

\section{Wastes}

Glycerol is one of the most tested low-cost carbon sources. Increasing biodiesel production generates high amounts of glycerol as a byproduct, raising its availability to the point of outpacing the market demand for glycerol (Yang et al. 2012). Furthermore, the raw glycerol derived from biodiesel production to be used in the oleochemical industries needs to undergo a costly and energyconsuming purification process, making it unappealing for those industries (Yen et al. 2012). Due to this, it becomes a potentially very cheap carbon source to be used in microbial lipid production. High yields and productivities were obtained using glycerol as carbon source for the yeasts Rhodosporidium toruloides (Yang et al. 2014a) and 
Cryptococcus curvatus (Ryu et al. 2013), respectively, making this cheap carbon source a promising feedstock. Furthermore, if the lipids produced are to be used for instance to produce biodiesel, the resulting glycerol can be recycled to produce more lipids.

Volatile fatty acids that can be obtained through syngas fermentation, lignocellulosic biomass degradation, and organic waste anaerobic digestion can also be an abundant low-cost or even negative cost carbon source. High productivities can be obtained using volatile fatty acids. Productivities of 0.28 and $0.33 \mathrm{~g} / \mathrm{L} / \mathrm{h}$ were obtained using glycerol plus volatile fatty acids and glycerol plus acetic acid, respectively (Fontanille et al. 2012). Fontanille et al. (2012) developed a two-stage fed-batch strategy where the yeast Yarrowia lipolytica was initially grown using glycerol, and, in a second stage, acetic acid or volatile fatty acids were added as carbon source for lipid accumulation. In this process, two low-cost carbon sources, like glycerol and volatile fatty acids, are used with success. $\mathrm{Xu}$ obtained a productivity of $0.8 \mathrm{~g} / \mathrm{L} / \mathrm{h}$ using diluted acetic acid as carbon source for the oleaginous yeast Yarrowia lipolytica in a semi-continuous system (Xu et al. 2017). The bioprocess developed by $\mathrm{Xu}$ managed not only to obtain high productivities but also to solve the main issue related with the dilute nature of the volatile fatty acids obtained by the processes mentioned previously, being able to sustain high-density cell culture using acetic acid at a concentration of only $3 \%$.

Whey permeate coming as a byproduct from cheese and butter creameries can also be used as cheap and abundant carbon source, since it has about $45 \mathrm{~g} / \mathrm{L}$ of lactose as the main carbon source. Ykema obtained a productivity of $0.995 \mathrm{~g} / \mathrm{L} / \mathrm{h}$ and a lipid yield of $0.29 \mathrm{~g} / \mathrm{g}$ using whey permeate as growth medium for Cryptococcus curvatus being the best productivities and lipid yields obtained using low-cost carbon sources (Ykema et al. 1988).

Flour-rich waste streams are also a promising abundant, cheap carbon source. Tsakona successfully utilized flour-rich waste and byproduct streams generated by bakery, confectionery, and wheat milling plants as the sole raw materials for lipid production by Lipomyces starkeyi achieving a productivity of $0.4 \mathrm{~g} / \mathrm{L} / \mathrm{h}$ (Tsakona et al. 2014).

Lignocellulosic hydrolysates have been widely studied as cheap carbon source for fermentation processes. Some oleaginous yeasts have the ability to utilize pentoses as well as hexoses and can assimilate glucose and xylose simultaneously (Hu et al. 2011), making this carbon source really promising. High lipid yields and productivities were obtained with the main sugars present in lignocellulosic hydrolysates. Gong obtained similar lipid yields by Lipomyces starkeyi using glucose, xylose, and cellobiose $(0.18 \mathrm{~g} / \mathrm{g} ; 0.18 \mathrm{~g} / \mathrm{g} ; 0.2 \mathrm{~g} / \mathrm{g})$ and a lipid productivity of $0.125 \mathrm{~g} / \mathrm{L} / \mathrm{h}$ using simultaneously xylose and cellobiose (Gong et al. 2012). Also, with Lipomyces starkeyi and using hemicellulose hydrolysate, Anschau obtained a lipid yield of $0.236 \mathrm{~g} / \mathrm{g}$ and a productivity of $0.111 \mathrm{~g} / \mathrm{L} / \mathrm{h}$ (Anschau et al. 2014). Fei, utilizing the yeast Rhodosporidium toruloides and using corn stove hydrolysate, was able to obtain a productivity of $0.4 \mathrm{~g} / \mathrm{L} / \mathrm{h}$ and a lipid yield of $0.29 \mathrm{~g} / \mathrm{g}$ (Fei et al. 2016).

Some of the wastes and wastewaters already have nitrogen source besides the carbon source, in some cases in high quantities, making it needed to add extra carbon sources to raise the $\mathrm{C} / \mathrm{N}$ ratio. One good example is the study of Ryo Byung-Gon where they use spent yeast from brewery industry as nutrient source for Cryptococcus curvatus (Ryu et al. 2013). In order to raise the $\mathrm{C} / \mathrm{N}$ ratio, they used glycerol and were able to achieve lipid yields of $0.22 \mathrm{~g} / \mathrm{g}$ and productivities of $0.152 \mathrm{~g} / \mathrm{L} / \mathrm{h}$. In the cases the nitrogen source is not present in enough quantity, corn steep liquor and domestic animal feces or urine can be used as cheap nitrogen sources (Park et al. 2014).

One way to avoid spending energy for sterilization is to find oleaginous yeasts able to outrun the competition when growing in non-sterile media. Yeasts, able to keep high productivities at low $\mathrm{pH}$ or at extreme temperatures or even capable to produce antimicrobial compounds, are good candidates for that. That is exactly what Santamauro found in the yeast Metschnikowia pulcherrima (Santamauro et al. 2014). This yeast has the ability to grow at low temperature and $\mathrm{pH}$ and to produce natural antimicrobial compounds. This yeast was not classified as oleaginous, but, in their study, they were able to obtain high yields at low temperature, low $\mathrm{pH}$, and using several different non-sterilized mediums with low-cost carbon sources and no yeast extract.

Further studies should be done to explore other carbon sources and to improve the productivities and lipid yields utilizing the cheap, abundant carbon sources available. A higher lipid yield would imply the use of less carbon source per unit of lipids produced, lowering in that way the production cost if there is a cost associated to the carbon source used. To improve the productivities and lipid yields, work should focus mainly in improving the fermentation process for better utilization of the low-cost carbon sources, explore the ability of some oleaginous yeasts to grow, and keep high productivities without needing to use sterile conditions and screening for other oleaginous yeast capable of achieving higher productivities and lipid yields with low-cost carbon sources or genetically engineering more robust yeasts for lipid production.

\section{Fermentation process}

As mentioned before, the fermentation process is where all the conditions must be optimized in order to obtain the highest lipid yields and productivities. To achieve that, there are different cultivation methods that can be used that require different kinds of fermenters that have different 
costs. Besides that, optimum temperature, aeration, and $\mathrm{pH}$ must be maintained for optimum production. The main costs of the fermentation process are related with the energy spent with the aeration and keeping the ideal temperature and with the size and type of fermenter used (fermenter cost). To minimize the influence of these costs, lipid productivity and lipid yield obtained in the process should be as high as possible. Fermenter costs are strongly dependent on the lipid productivity (Ykema et al. 1988); so, higher productivities would allow to use smaller fermenters to obtain the same quantities of lipids and consequently lower fermenter cost and the energy spent. Also, the cultivation method has big influence in the lipid yields and productivities. Ykema compared four different cultivation methods (batch, fed-batch, continuous, and partial recycling culture) for lipid production with Cryptococcus curvatus and concluded that the highest lipid productivities will be achieved in a mode of operation that enables the cultivation at high cell densities (Ykema et al. 1988). According to Ykema, the highest productivities can be achieved using partial recycling culture of the biomass, followed by fed-batch, continuous, and batch method. Batch mode is mainly used in lab-scale studies using flasks for screening for new oleaginous yeasts, to assess the potential of the oleaginous yeasts and determine the optimum cultivation conditions. Considering that, it is possible to raise the productivities of many of the studies referenced in Tables 2, 3, 4, 5, and 6. Until now, the highest productivities by Rhodotorula glutinis, Yarrowia lipolytica, Rhodosporidium toruloides, and Lipomyces starkeyi were achieved using fed-batch cultivation methods. The highest lipid productivity obtained until now was with Lipomyces starkeyi as reported by Lin that used a two-stage fermentation method, where, in the first stage, cells were cultivated in a nutrient-rich medium for cell growth and, in the second stage, to promote lipid accumulation, cells were resuspended in a glucose solution, and, when the glucose was exhausted, more glucose was supplemented for more lipid accumulation (Lin et al. 2011).

Although, methods like continuous cultivation have been tested with several oleaginous yeasts, methods like partial recycling culture that allowed for the highest productivity were tested with Cryptococcus curvatus, only. Therefore, although fed-batch is recognized as a great method for high cell density cultivation, other methods should be tested and developed to further improve the lipid productivities of the various oleaginous yeasts.

Several of the oleaginous yeasts are obligate aerobes, depending on oxygen for its energy metabolism and cellular component synthesis. For those, the aeration has a big influence in the lipid productivities obtained, since good levels of dissolved oxygen are required for higher cell growth (Yong-Hong et al. 2006) (Choi et al. 1982).
At high cell density, culture viscosity is higher and mass transfer is harder, reducing oxygen availability. Pan was able to obtain much higher biomass concentrations of Rhodotorula glutinis and higher overall lipid productivities in a fed-batch process, using aeration with oxygenenriched air instead of air (Pan et al. 1986). However, the effects of oxygen limitation appear to differ widely among lipogenic yeasts since for some of the yeasts the oxygen limitation seems to result in lower lipid productivities despite of the higher cell growth (Calvey et al. 2016). Higher aeration rates may improve lipid productivity of some yeasts, but it has a cost since it implies to spend a higher amount of energy. In order to reduce the aeration requirements, different aeration rates can be used promoting a lower aeration in the lipid accumulation stage, and another option is to select yeasts that require lower aeration rates. Contributions to reduce the aeration requirements were mentioned in co-culture studies of oleaginous yeasts with microalgae due to the release of oxygen to the medium by the microalgae (Xue et al. 2010; Cheirsilp et al. 2012). Xue, when assessing the lipid production of mix cultivation of Spirulina platensis and Rhodotorula glutinis, registered a rapid increase in dissolved oxygen from 7.45 to $120.5 \%$ in $5 \mathrm{~h}$ when Spirulina platensis was added to the culture (Xue et al. 2010).

Aeration not only influences the lipid productivity but also the lipid profile of some yeasts. Davies studied the effect of low oxygen uptake rate on the fatty acid profile of the oleaginous yeast Cryptococcus curvatus and observed that it was possible to decrease the unsaturated fatty acids percentage in the lipid profile by limiting the oxygen uptake rate of the culture (Davies et al. 1990). To decrease unsaturated fatty acids is a way to obtain cocoa butter equivalent (Hassan et al. 1994) or palm oil equivalent (Sargeant et al. 2014), but doing that by limiting the oxygen uptake rate can lower the lipid yields and productivities (Davies et al. 1990).

Temperature is another factor affecting lipid yield and productivity. In large-scale production, yeasts should be robust to withstand process disturbances, like temperature and $\mathrm{pH}$ variations, without affecting much the productivity, and the ability to keep good productivities at high temperatures would be advantageous to decrease the amount of cooling needed for cultivation (Lamers et al. 2016). A selection of robust yeasts and yeasts tolerant to high temperatures would be favorable for large-scale production and to reduce the energy spent in the fermentation process. Amaretti et al. (2010) and Viñarta et al. (2016) assessed the potential of several yeasts isolated from cold environments like Antarctica. The results they obtained were promising in terms of lipid yields and productivities, and the yeasts were robust being able to grow at a wide range of temperatures, but not at high temperatures. More screening should be done to find 
robust yeasts able to achieve high lipid yields and productivities at high temperatures.

\section{Downstream processing}

In the downstream processing, the main costs are associated with the energy spent in the process of recovery of the lipids due to the fact that the lipids are stored inside the cells. The traditional processes involve the cell mass washing and recovery and the lipid extraction where solvents are used. High density cell cultivations are also advantageous in this stage since it contributes to reduce the energy needed in processes like centrifugation due to the less water that needs to be separated from the cells (Ling et al. 2013). The lipid extraction process is an energy-intensive process involving high amounts of toxic solvents that requires cell disruption for an effective extraction (Yu et al. 2015). The process of recovering the lipids would become much more simple and cheap if the lipids were excreted to the medium. This could possibly be achieved through genetic engineering or exploring the natural ability of secreting the lipids to the medium that some yeasts have under certain conditions (Huang et al. 2018). Many cell disruption methods are available and can be divided in mechanical and non-mechanical methods. Their efficiencies can be different depending on the microorganism used, and the lipid applications should also be taken in consideration when choosing the extraction method. For instance, when the lipids are for food industry, toxic chemicals should be avoided so that a wise choice should be done (Ochsenreither et al. 2016). Lipid recovery from wet oleaginous microbial biomass has been highly investigated since it would contribute to a significant reduction of the energy spent in dewatering the cell biomass, but the technologies developed until now are far from being ready to be commercialized (Dong et al. 2016).

To help to improve the economics of yeast lipid production, another solution could be the recovery of highvalue products that some yeasts produce simultaneously with lipids, like enzymes, beta-carotene and astaxanthin. Several studies have been made about the co-production of lipids and carotenoids with promising results (Kot et al. 2017; Saenge et al. 2011). Carotenoids are high-value products, with a continuously growing global market expected to reach about US\$1.4 billion in 2018 (MataGómez et al. 2018); and its recovery alongside with the lipids production is appealing. The possibility of exploring other high-value products from oleaginous yeast should be further assessed to improve the economics of yeast lipid production.

In Fig. 2, the main points of improvement to lower production costs in the three main stages of the production process are presented.

\section{Potential applications for oleaginous yeast oils}

The studies on the production of lipids from oleaginous yeasts have been done mainly with the goal of using those lipids for biodiesel production. Their lipid profile similar to vegetable oils makes them suitable for biodiesel production, although different lipid profiles can be found in different oleaginous yeasts. The lipid profile of each yeast also depends on the culture conditions, making it possible to direct their lipid profile to lipid profiles more favorable to other applications. Metabolic engineering of the yeasts could also be used for tailoring the lipid profile to the desired products (Dey and Maiti 2013).

\section{Biodiesel}

In the last decades, the global biodiesel production started raising mainly due to the European Union (EU) Renewable Energy Directive (RED) that requires $10 \%$ of all transport fuels to be delivered from renewable sources by 2020 in every Member State being more than $85 \%$ of the RED transport target expected to come from biofuels (Biodiesel is the main biofuel in the EU transport sector, with a $78.2 \%$ share of total consumption, by energy, according to Eurostat 2013). This demand started raising many concerns related with the sustainability of its production, mainly the biodiesel of first generation, obtained using food crops (Anuar and Zuhairi 2016). EU specified a minimum set of sustainability criteria for biofuels and bioliquids, with a threshold of $35 \%$ savings of GHG emissions with respect to the fossil fuels they replace. The use of specific land-use categories, such as primary forest, highly biodiverse grassland, wetlands, and peatlands, is explicitly excluded due to its lack of sustainability. Oleaginous yeasts have a favorable lipid profile for the production of biodiesel, due to their high percentage of oleic acid, and they are a potential solution for all the sustainability issues related with first-generation biodiesel production. This is why so many studies have been done with oleaginous yeasts with the goal of producing lipids for biodiesel. Biodiesel production is expected to contract slightly by 2020 according to the trajectories presented by the Member States in their National Renewable Action Plans (Marelli et al. 2015), but if oleaginous yeast oils become a sustainable solution for biodiesel production, then the demand can raise again.

\section{Food industry}

There are many applications for vegetable oils in the food industry. Not only the vegetable oils are sold for cooking purposes, but they are also part of many food products. Oleaginous yeast oils could get into the market as sustainable vegetable oil equivalents since their lipid profile is 
Fig. 2 Main points of improvement to lower production costs in the three main stages of the production process

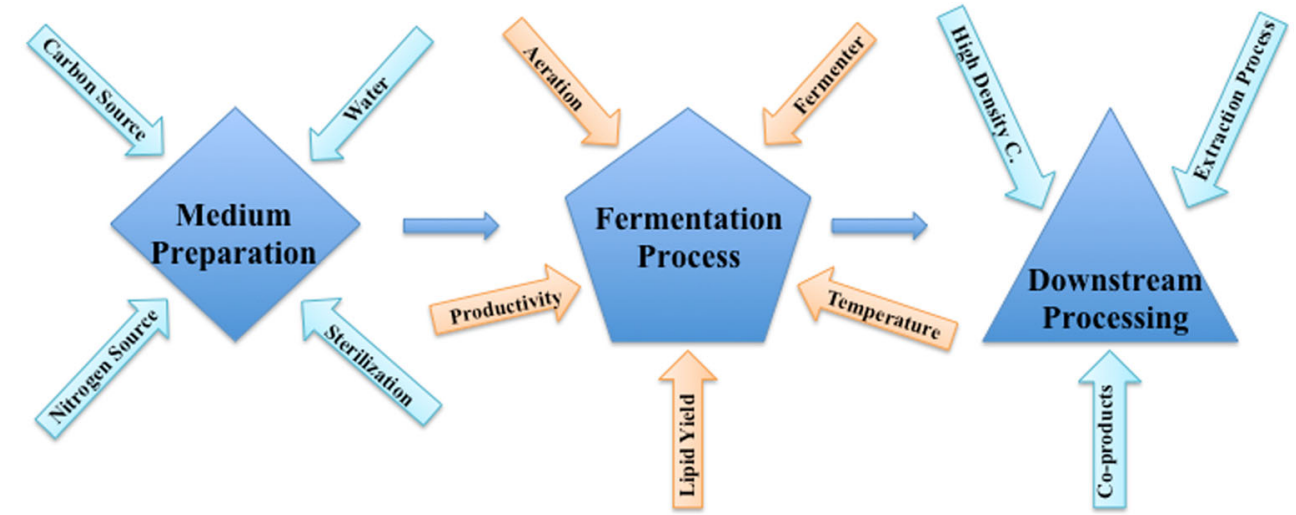

similar to vegetable oils. Palm oil is one of the most used oils in the food industry, and it is produced in tropical regions where it contributes to a $1.5 \%$ annual rate of deforestation of tropical rainforests (Sargeant et al. 2014). Its lipid profile is high in saturated fatty acids, making it necessary to raise the percentage of saturated fatty acids in the oleaginous yeasts oil to obtain a lipid profile more similar to palm oil in order to be possible to be used as palm oil equivalent. The palm oil selling price is low, making it challenging to find a substitute cost competitive, but, by finding it, it would be of high environmental interest. It could be financially more interesting to develop oil yeast equivalents to high-value fats like cocoa butter. Like palm oil, cocoa butter lipid profile is also high in saturated fatty acids making it is also necessary to tailor the fatty acid profile of the oleaginous yeasts. Tailoring the lipid profile of the oleaginous yeasts to produce higher amounts of essential fatty acids for nutrition could be also advantageous.

\section{Biopolymers}

Polymers are mostly derived from petrochemicals, which raises environmental concerns. Public awareness of those environmental issues is raising the search for greener biobased alternatives. Biopolymers obtained from vegetable oils can become a good alternative to petrochemicals if sustainable vegetable oils are used. Oleaginous yeast oils can be a sustainable alternative to vegetable oils also for biopolymer production. Furthermore, the composition of vegetable oils can vary significantly, affecting the quality of the polymer production (Zhang et al. 2017), which is not the case for the production of oil from OY.

Many polymers can be obtained using vegetable oils, mainly polyurethane, polyester, polyether, and polyolefin. Polyurethanes are synthesized by reacting polyols with petroleum-derived multi-isocyanate, both of which could be derived from triglycerides and their derivatives (Miao et al. 2014). With polyols, flexible or rigid foams can be manufactured that can be used in a wide range of products, which goes from vehicle interiors and building insulation until the core of surf boards. The production of biopolymers is also useful for biomedical applications mainly because vegetable oil is a bio-based raw material that can be metabolized in the human body, and, therefore, materials derived from them are potentially biocompatible (Ca et al. 2013). A huge market can be explored if the production of oleaginous yeasts oil becomes competitive.

\section{Others}

Other applications can be found in pharmaceutical and cosmetic industries, and several others should be researched aiming at finding high-value products to raise

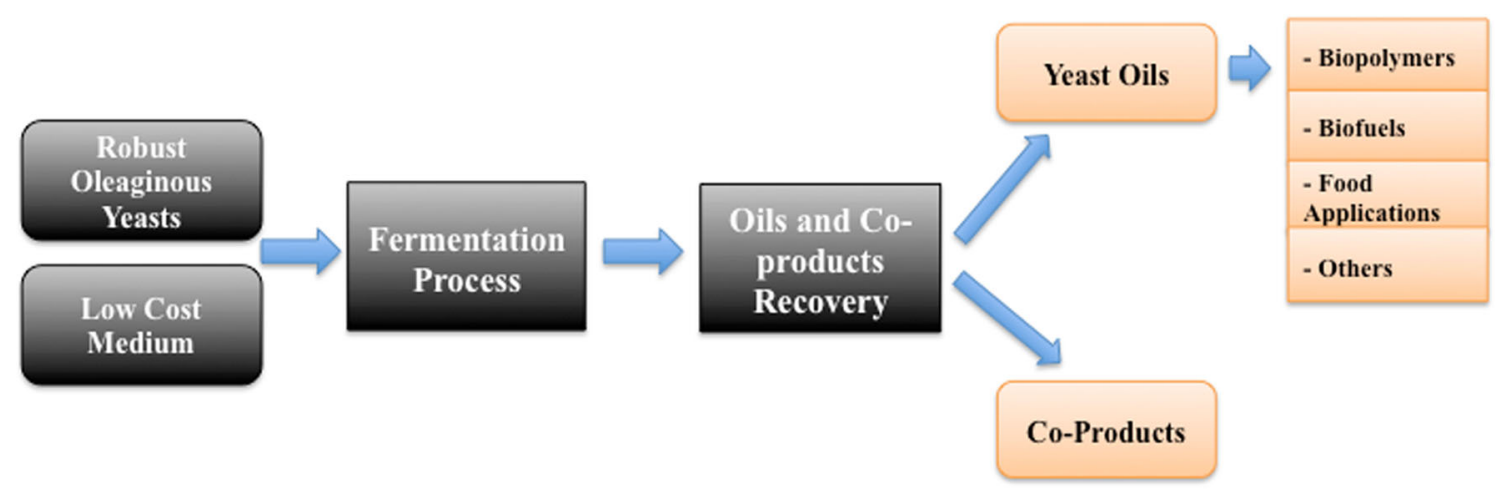

Fig. 3 Envisioned yeast lipid production and applications 
the income of oleaginous yeast oils and turn its production more profitable and viable even at small scale.

\section{Conclusions}

Oleaginous yeasts have great potential for sustainable production of oils similar to vegetable oils. The high potential comes from their ability to utilize several kinds of low-cost substrates, high growth rate and lipid production, small amount of land and water requirements, and the simple cultivation methods that are not climate-affected.

Despite all the potential they have, a lot of research still needs to be done to improve the economics of yeast oil production. Screening for more robust oleaginous yeasts, or even genetically manipulating them to obtain high lipid yields and productivities, utilizing a wide variety of low-cost carbon sources in non-sterile media and the possibility of operating at a wide range of $\mathrm{pH}$ and temperatures, mainly high temperatures, would significantly improve the economics of the lipid production by reducing the costs in energy spent and by using carbon sources obtained locally. Considering that the carbon source can contribute to over $60 \%$ of the total production costs if glucose is used, a wider range of low-cost substrates should be evaluated, as a successful use of negative cost carbon source would have a significant impact in the reduction of the production costs. In the fermentation process, further research should be done to develop better fermentation methods to raise the lipid yield and productivities together with the use of cheaper and more energyeffective fermenters as this would also considerably improve the economics of lipid production by reducing the capital investment and energy spent and by raising the productivity. Oil recovery processes should also keep being improved to reduce the energy and solvent usage, and high-value co-products recovery should also be implemented if the amount of co-product obtained justifies the investment. The ability of the oleaginous yeasts of producing oils with different lipid profiles should be further explored, since the production of oils with different profiles could be directed for the production of different products like biodiesel, vegetable oil substitutes, food additives, biopolymers, pharmaceutical and cosmetic industries, etc., widening the market for yeast oils. To direct the lipid profile of the oils for the production of high-value products would significantly improve the economics of yeast lipid production.

In Fig. 3, we can see in a schematic way the conclusions of this work. To improve the economics of oleaginous yeast oil production, we should reduce production costs in all stages, improve lipid yields and productivities, and direct the production to high-value products.
Acknowledgements This study was supported by the Portuguese Foundation for Science and Technology (FCT) under the scope of the strategic funding of UID/BIO/04469/2013 unit and COMPETE 2020 (POCI-01-0145-FEDER-006684), FCT doctoral grant (SFRH/BD/ 80490/2011) attributed to Bruno Vasconcelos, and BioTecNorte operation (NORTE-01-0145-FEDER-000004) funded by the European Regional Development Fund under the scope of Norte2020 - Programa Operacional Regional do Norte.

\section{Compliance with ethical standards}

Conflict of interest Bruno Vasconcelos declares that he has no conflict of interest. José Carlos Teixeira declares that he has no conflict of interest. Giuliano Dragone declares that he has no conflict of interest. José António Teixeira declares that he has no conflict of interest.

Human and animal studies This article does not contain any studies with human participants or animals performed by any of the authors.

\section{References}

Ageitos JM, Vallejo JA, Veiga-crespo P, Villa TG (2011) Oily yeasts as oleaginous cell factories. Appl Microbiol Biotechnol 90:12191227. https://doi.org/10.1007/s00253-011-3200-z

Alvarez RM, Rodriguez B, Romano JM, Diaz AO, Mir D, Navarro L, Saura G, Garcia JL (1992) Lipid accumulation in Rhodotorula glutinis on sugar cane molasses in single-stage continuous culture. J Microbiol 8:214-215

Amaretti A, Raimondi S, Sala M, Roncaglia L, De Lucia M, Leonardi A, Rossi M (2010) Single cell oils of the cold-adapted oleaginous yeast Rhodotorula glacialis DBVPG 4785. Microb Cell Factories 9:1-6. https://doi.org/10.1186/1475-2859-9-73

Annamalai N, Sivakumar N, Oleskowicz-Popiel P (2018) Enhanced production of microbial lipids from waste office paper by the oleaginous yeast Cryptococcus curvatus. Fuel 217:420-426. https://doi. org/10.1016/j.fuel.2017.12.108

Anschau A, Xavier MCA, Hernalsteens S, Franco TT (2014) Effect of feeding strategies on lipid production by Lipomyces starkeyi. Bioresour Technol 157:214-222. https://doi.org/10.1016/j.biortech. 2014.01.104

Anuar MR, Zuhairi A (2016) Challenges in biodiesel industry with regards to feedstock, environmental, social and sustainability issues: a critical review. Renew Sust Energ Rev 58:208-223. https://doi. org/10.1016/j.rser.2015.12.296

Ca V, Lligadas G, Ronda JC, Galia M (2013) Renewable polymeric materials from vegetable oils: a perspective. 16:337-343. https:// doi.org/10.1016/j.mattod.2013.08.016

Calvey CH, Su YK, Willis LB, McGee M, Jeffries TW (2016) Nitrogen limitation, oxygen limitation, and lipid accumulation in Lipomyces starkeyi. Bioresour Technol 200:780-788. https://doi.org/10.1016/j. biortech.2015.10.104

Cheirsilp B, Kitcha S, Torpee S (2012) Co-culture of an oleaginous yeast Rhodotorula glutinis and a microalga Chlorella vulgaris for biomass and lipid production using pure and crude glycerol as a sole carbon source. Ann Microbiol 62:987-993. https://doi.org/10.1007/ s13213-011-0338-y

Choi SY, Ryu DD, Rhee JS (1982) Production of microbial lipid: effects of growth rate and oxygen on lipid synthesis and fatty acid composition of Rhodotorula gracilis. Biotechnol Bioeng 24:1165-1172. https://doi.org/10.1002/bit.260240513

Cui Y, Liang Y (2015) Sweet sorghum syrup as a renewable material for microbial lipid production. Biochem Eng J 93:229-234. https://doi. org/10.1016/j.bej.2014.09.013 
Dai C, Tao J, Xie F, Dai Y, Zhao M (2007) Biodiesel generation from oleaginous yeast Rhodotorula glutinis with xylose assimilating capacity. J Biotechnol 6:2130-2134

Davies RJ, Holdsworth JE, Reader SL (1990) The effect of low oxygen uptake rate on the fatty acid profile of the oleaginous yeast Apiotriehum curvature. Appl Microbiol Biotechnol 33:569-573. https://doi.org/10.1007/BF00172553

Dey P, Maiti MK (2013) Molecular characterization of a novel isolate of Candida tropicalis for enhanced lipid production. J Appl Microbiol 114:1357-1368. https://doi.org/10.1111/jam.12133

Dobrowolski A, Mituła P, Rymowicz W, Mirończuk AM (2016) Efficient conversion of crude glycerol from various industrial wastes into single cell oil by yeast Yarrowia lipolytica. Bioresour Technol 207: 237-243. https://doi.org/10.1016/j.biortech.2016.02.039

Dong T, Knoshaug EP, Pienkos PT, Laurens LML (2016) Lipid recovery from wet oleaginous microbial biomass for biofuel production: a critical review. Appl Energy 177:879-895. https://doi.org/10.1016/ j.apenergy.2016.06.002

El-Saied HM, Morsi MK, Amer MMA (1981) Composition of cocoa shell fat as related to cocoa butter. Z Ernahrungswiss 20:145-151. https://doi.org/10.1007/BF02021260

Fassinou WF, Sako A, Fofana A, Koua KB, Toure S (2010) Fatty acids composition as a means to estimate the high heating value (HHV) of vegetable oils and biodiesel fuels. Energy 35:4949-4954. https:// doi.org/10.1016/j.energy.2010.08.030

Fei Q, Chang HN, Shang L, Choi J (2011a) Exploring low-cost carbon sources for microbial lipids production by fed-batch cultivation of Cryptococcus albidus. Biotechnol Bioprocess Eng 16:482-487. https://doi.org/10.1007/s12257-010-0370-y

Fei Q, Chang HN, Shang L, Choi JD, Kim NJ, Kang JW (2011b) The effect of volatile fatty acids as a sole carbon source on lipid accumulation by Cryptococcus albidus for biodiesel production. Bioresour Technol 102:2695-2701. https://doi.org/10.1016/j. biortech.2010.10.141

Fei Q, O'Brien M, Nelson R, Chen X, Lowell A, Dowe N (2016) Enhanced lipid production by Rhodosporidium toruloides using different fed-batch feeding strategies with lignocellulosic hydrolysate as the sole carbon source. Biotechnol Biofuels 9:1-12. https://doi. org/10.1186/s13068-016-0542-x

Fontanille P, Kumar V, Christophe G, Nouaille R, Larroche C (2012) Bioconversion of volatile fatty acids into lipids by the oleaginous yeast Yarrowia lipolytica. Bioresour Technol 114:443-449. https:// doi.org/10.1016/j.biortech.2012.02.091

Gerbens-Leenes W, Hoekstra AY, van der Meer TH (2009) The water footprint of bioenergy. Proc Natl Acad Sci 106:10219-10223. https://doi.org/10.1073/pnas.0812619106

Gong Z, Wang Q, Shen H, Hu C, Jin G, Zhao ZK (2012) Co-fermentation of cellobiose and xylose by Lipomyces starkeyi for lipid production. Bioresour Technol 117C:20-24. https://doi.org/10.1016/j.biortech. 2012.04.063

Gong Z, Shen H, Yang X, Wang Q, Xie H, Zhao ZK (2014) Lipid production from corn stover by the oleaginous yeast Cryptococcus curvatus. Biotechnol Biofuels 7:158. https://doi.org/10.1186/ s13068-014-0158-y

Gong Z, Zhou W, Shen H, Zhao ZK, Yang Z, Yan J, Zhao M (2016) Coutilization of corn stover hydrolysates and biodiesel-derived glycerol by Cryptococcus curvatus for lipid production. Bioresour Technol 219:552-558. https://doi.org/10.1016/j.biortech.2016.08.021

Hassan M, Blanc PJ, Pareilleux A, Goma G (1994) Production of singlecell oil from prickly- pear juice fermentation by Cryptococcus curvatus grown in batch culture. Microbiology 1:1994-1994

Hu C, Wu S, Wang Q, Jin G, Shen H, Zhao ZK (2011) Simultaneous utilization of glucose and xylose for lipid production by Trichosporon cutaneum. Biotechnol Biofuels 4:25. https://doi.org/ $10.1186 / 1754-6834-4-25$
Huang C, Zong M, Wu H, Liu Q (2009) Microbial oil production from rice straw hydrolysate by Trichosporon fermentans. Bioresour Technol 100:4535-4538. https://doi.org/10.1016/j. biortech.2009.04.022

Huang C, Wu H, Liu Z-J, Cai J, Lou W-Y, Zong M-H (2012) Effect of organic acids on the growth and lipid accumulation of oleaginous yeast Trichosporon fermentans. Biotechnol Biofuels 5:4. https://doi. org/10.1186/1754-6834-5-4

Huang C, Cui X, Wu H, Lou W, Zong M (2014) The effect of different factors on microbial oil production by Trichosporon fermentans on rice straw acid hydrolysate. Int J Green Energy 11:787-795. https:// doi.org/10.1080/15435075.2013.829779

Huang XF, Liu JN, Lu LJ, Peng KM, Yang GX, Liu J (2016) Culture strategies for lipid production using acetic acid as sole carbon source by Rhodosporidium toruloides. Bioresour Technol 206:141-149. https://doi.org/10.1016/j.biortech.2016.01.073

Huang XF, Shen Y, Luo HJ, Liu JN, Liu J (2018) Enhancement of extracellular lipid production by oleaginous yeast through preculture and sequencing batch culture strategy with acetic acid. Bioresour Technol 247:395-401. https://doi.org/10.1016/j.biortech.2017.09. 096

Johnson VW, Singh M, Saini VS, Adhikari DK, Sista V, Yadav NK (1995) Utilization of molasses for the production of fat by an oleaginous yeast, Rhodotorula glutinis IIP-30. J Ind Microbiol 14:1-4. https://doi.org/10.1007/BF01570057

Karamerou EE, Theodoropoulos C, Webb C (2016) A biorefinery approach to microbial oil production from glycerol by Rhodotorula glutinis. Biomass Bioenergy 89:113-122. https://doi.org/10.1016/j. biombioe.2016.01.007

Kot AM, Kurcz A, Bry J, Gientka I, Bzducha-wróbel A, Maliszewska M, Reczek L (2017) Effect of initial pH of medium with potato wastewater and glycerol on protein, lipid and carotenoid biosynthesis by Rhodotorula glutinis. 27:25-31. https://doi.org/10.1016/j.ejbt.2017.01.007

Koutinas AA, Chatzifragkou A, Kopsahelis N, Papanikolaou S, Kookos IK (2014) Design and techno-economic evaluation of microbial oil production as a renewable resource for biodiesel and oleochemical production. Fuel 116:566-577. https://doi.org/10.1016/j.fuel.2013. 08.045

Lamers D, van Biezen N, Martens D, Peters L, van de Zilver E, Jacobsvan Dreumel N, Wijffels RH, Lokman C (2016) Selection of oleaginous yeasts for fatty acid production. BMC Biotechnol 16:45. https://doi.org/10.1186/s12896-016-0276-7

Li Y, Zhao Z, Bai F, Kent Z (2007) High-density cultivation of oleaginous yeast Rhodosporidium toruloides Y4 in fed-batch culture. Enzym Microb Technol 41:312-317. https://doi.org/10.1016/j.enzmictec. 2007.02.008

Lin J, Shen H, Tan H, Zhao X, Wu S, Hu C, Zhao ZK (2011) Lipid production by Lipomyces starkeyi cells in glucose solution without auxiliary nutrients. J Biotechnol 152:184-188. https://doi.org/10. 1016/j.jbiotec.2011.02.010

Ling J, Nip S, Shim H (2013) Enhancement of lipid productivity of Rhodosporidium toruloides in distillery wastewater by increasing cell density. Bioresour Technol 146:301-309. https://doi.org/10. 1016/j.biortech.2013.07.023

Ling J, Tian Y, de Toledo RA, Shim H (2017) Cost reduction for the lipid production from distillery and domestic mixed wastewater by Rhodosporidium toruloides via the reutilization of spent seed culture medium. Energy 136:135-141. https://doi.org/10.1016/j.energy. 2016.04.008

Liu Y, Wang Y, Liu H, Zhang J (2015) Enhanced lipid production with undetoxified corncob hydrolysate by Rhodotorula glutinis using a high cell density culture strategy. Bioresour Technol 180:32-39. https://doi.org/10.1016/j.biortech.2014.12.093

Liu J, Huang X, Chen R, Yuan M, Liu J (2017) Efficient bioconversion of high-content volatile fatty acids into microbial lipids by 
Cryptococcus curvatus ATCC 20509. Bioresour Technol 239:394 401. https://doi.org/10.1016/J.BIORTECH.2017.04.070

Lopes M, Gomes AS, Silva CM, Belo I (2018) Microbial lipids and added value metabolites production by Yarrowia lipolytica from pork lard. J Biotechnol 265:76-85. https://doi.org/10.1016/j.jbiotec.2017.11. 007

Lorenz E, Runge D, Marbà-Ardébol AM, Schmacht M, Stahl U, Senz M (2017) Systematic development of a two-stage fed-batch process for lipid accumulation in Rhodotorula glutinis. J Biotechnol 246:4-15. https://doi.org/10.1016/j.jbiotec.2017.02.010

Magdouli S, Guedri T, Tarek R, Brar SK, Blais JF (2017) Valorization of raw glycerol and crustacean waste into value added products by Yarrowia lipolytica. Bioresour Technol 243:57-68. https://doi.org/ 10.1016/j.biortech.2017.06.074

Marelli L, Padella M, Edwards R, Moro A, Kousoulidou M, Giuntoli J, Baxter D, Vorkapic V, O'Connell A, Lonza L (2015) The impact of biofuels on transport and the environment, and their connection with agricultural development in Europe

Mata-Gómez LC, Montañez JC, Méndez-zavala A, Aguilar CN (2018) Biotechnological production of carotenoids by yeasts: an overview. $1-11$

Meesters PAEP, Huijberts GNM, Eggink G (1996) High-cell-density cultivation of the lipid accumulating yeast Cryptococcus curvatus using glycerol as a carbon source. Appl Microbiol Biotechnol 45:575579. https://doi.org/10.1007/s002530050731

Miao S, Wang P, Su Z, Zhang S (2014) Vegetable-oil-based polymers as future polymeric biomaterials. Acta Biomater 10:1692-1704. https://doi.org/10.1016/J.ACTBIO.2013.08.040

Ochsenreither K, Glück C, Stressler T, Fischer L, Syldatk C (2016) Production strategies and applications of microbial single cell oils. Front Microbiol 7. https://doi.org/10.3389/fmicb.2016.01539

Pan JG, Kwak MY, Rhee JS (1986) High density cell-culture of Rhodtorula Glutinis using oxygen-enriched air. Biotechnol Lett 8: 715-718

Papanikolaou S, Aggelis G (2002) Lipid production by Yarrowia lipolytica growing on industrial glycerol in a single-stage continuous culture. Bioresour Technol 82:43-49

Papanikolaou S, Aggelis G (2011) Lipids of oleaginous yeasts. Part II: technology and potential applications. Eur J Lipid Sci Technol 113: 1052-1073. https://doi.org/10.1002/ejlt.201100015

Park GW, Fei Q, Jung K, Chang HN, Kim YC, Kim NJ, Choi JD, Kim S, Cho J (2014) Volatile fatty acids derived from waste organics provide an economical carbon source for microbial lipids/biodiesel production. Biotechnol J 9:1536-1546. https://doi.org/10.1002/biot. 201400266

Park GW, Chang HN, Jung K, Seo C, Kim YC, Choi JH, Woo HC, Hwang IJ (2017) Production of microbial lipid by Cryptococcus curvatus on rice straw hydrolysates. Process Biochem 56:147153. https://doi.org/10.1016/j.procbio.2017.02.020

Probst KV, Vadlani PV (2015) Production of single cell oil from Lipomyces starkeyi ATCC 56304 using biorefinery by-products. Bioresour Technol 198:268-275. https://doi.org/10.1016/j.biortech. 2015.09.018

Probst KV, Schulte LR, Durrett TP, Rezac ME, Probst KV, Schulte LR, Durrett TP, Rezac ME, Probst KV, Schulte LR, Durrett TP, Rezac ME, Vadlani PV (2017) Oleaginous yeast: a value-added platform for renewable oils. 8551. https://doi.org/10.3109/07388551.2015. 1064855

Qiao K, Wasylenko TM, Zhou K, Xu P, Stephanopoulos G (2017) Lipid production in Yarrowia lipolytica is maximized by engineering cytosolic redox metabolism. Nat Biotechnol 35:173-177. https://doi. org/10.1038/nbt.3763

Qin L, Liu L, Zeng AP, Wei D (2017) From low-cost substrates to single cell oils synthesized by oleaginous yeasts. Bioresour Technol 245: 1507-1519. https://doi.org/10.1016/j.biortech.2017.05.163
Ratledge C (1991) Microorganisms for lipids. Acta Biotechnol 11:429438. https://doi.org/10.1002/abio.370110506

Ratledge C (2002) Regulation of lipid accumulation in oleaginous microorganisms. Biochem Soc Trans 30:1047-1050

Ratledge C, Cohen Z (2008) Microbial and algal oils: do they have a future for biodiesel or as commodity oils? Lipid Technol 20:155160. https://doi.org/10.1002/lite.200800044

Ricardo C, José C, Neto D, Thomaz V, Bittencourt E, Scopel E, Bianchi A, Medeiros P, Porto L, Vandenberghe DS (2017) Pilot scale biodiesel production from microbial oil of Rhodosporidium toruloides DEBB 5533 using sugarcane juice : performance in diesel engine and preliminary economic study. Bioresour Technol 223:259-268. https://doi.org/10.1016/j.biortech.2016.10.055

Ryu B-G, Kim J, Kim K, Choi Y-E, Han J-I, Yang J-W (2013) High-celldensity cultivation of oleaginous yeast Cryptococcus curvatus for biodiesel production using organic waste from the brewery industry. Bioresour Technol 135:357-364. https://doi.org/10.1016/j.biortech. 2012.09.054

Saenge C, Cheirsilp B, Tachapattaweawrakul T, Bourtoom T, Suksaroge TT (2011) Potential use of oleaginous red yeast Rhodotorula glutinis for the bioconversion of crude glycerol from biodiesel plant to lipids and carotenoids. Process Biochem 46:210-218. https://doi.org/10. 1016/j.procbio.2010.08.009

Santamauro F, Whiffin FM, Scott RJ, Chuck CJ (2014) Low-cost lipid production by an oleaginous yeast cultured in non-sterile conditions using model waste resources. Biotechnol Biofuels 7:34. https://doi. org/10.1186/1754-6834-7-34

Sara M, Brar SK, Blais JF (2016) Lipid production by Yarrowia lipolytica grown on biodiesel-derived crude glycerol: optimization of growth parameters and their effects on the fermentation efficiency. RSC Adv 6:90547-90558. https://doi.org/10.1039/C6RA16382C

Saran S, Mathur A, Dalal J, Saxena RK (2017) Process optimization for cultivation and oil accumulation in an oleaginous yeast Rhodosporidium toruloides A29. Fuel 188:324-331. https://doi. org/10.1016/j.fuel.2016.09.051

Sargeant LA, Chuck CJ, Donnelly J, Bannister CD, Scott RJ (2014) Optimizing the lipid profile, to produce either a palm oil or biodiesel substitute, by manipulation of the culture conditions for Rhodotorula glutinis. 5:33-43

Seo YH, Lee I, Jeon SH, Han JI (2014) Efficient conversion from cheese whey to lipid using Cryptococcus curvatus. Biochem Eng J 90:149153. https://doi.org/10.1016/j.bej.2014.05.018

Sitepu IR, Sestric R, Ignatia L, Levin D, German JB, Gillies LA, Almada LAG, Boundy-Mills KL (2013) Manipulation of culture conditions alters lipid content and fatty acid profiles of a wide variety of known and new oleaginous yeast species. Bioresour Technol 144:360-369. https://doi.org/10.1016/j.biortech.2013.06.047

Sitepu IR, Garay LA, Sestric R, Levin D, Block DE, German JB, Boundy-Mills KL (2014) Oleaginous yeasts for biodiesel: current and future trends in biology and production. Biotechnol Adv 32: 1336-1360. https://doi.org/10.1016/j.biotechadv.2014.08.003

Thiru M, Sankh S, Rangaswamy V (2011) Process for biodiesel production from Cryptococcus curvatus. Bioresour Technol 102:1043610440. https://doi.org/10.1016/j.biortech.2011.08.102

Tinoi J, Rakariyatham N (2016) Optimization of pineapple pulp residue hydrolysis for lipid production by Rhodotorula glutinis TISTR5159 using as biodiesel feedstock. Biosci Biotechnol Biochem 80:16411649. https://doi.org/10.1080/09168451.2016.1177444

Tsakona S, Kopsahelis N, Chatzifragkou A, Papanikolaou S, Kookos IK, Koutinas AA (2014) Formulation of fermentation media from flourrich waste streams for microbial lipid production by Lipomyces starkeyi. J Biotechnol 189:36-45. https://doi.org/10.1016/J. JBIOTEC.2014.08.011

Tsigie YA, Wang CY, Truong CT, Ju YH (2011) Lipid production from Yarrowia lipolytica Polg grown in sugarcane bagasse hydrolysate. 
Bioresour Technol 102:9216-9222. https://doi.org/10.1016/j. biortech.2011.06.047

Uçun Kiran E, Trzcinski A, Webb C (2013) Microbial oil produced from biodiesel by-products could enhance overall production. Bioresour Technol 129:650-654. https://doi.org/10.1016/j.biortech.2012.11. 152

Vieira JPF, Ienczak JL, Rossell CEV, Pradella JGC, Franco TT (2014) Microbial lipid production: screening with yeasts grown on Brazilian molasses. Biotechnol Lett 36:2433-2442. https://doi.org/ 10.1007/s10529-014-1624-0

Viñarta SC, Angelicola MV, Barros JM, Fernández PM, Mac Cormak W, Aybar MJ, de Figueroa LIC (2016) Oleaginous yeasts from Antarctica: screening and preliminary approach on lipid accumulation. J Basic Microbiol 56:1360-1368. https://doi.org/10.1002/ jobm.201600099

Wang R, Wang J, Xu R, Fang Z, Liu A (2014) Oil production by the oleaginous yeast Lipomyces starkeyi using diverse carbon sources. BioResources 9:7027-7040. https://doi.org/10.15376/biores.9.4. 7027-7040

Whiffin F, Santomauro F, Chuck CJ (2016) Toward a microbial palm oil substitute: oleaginous yeasts cultured on lignocellulose. Biofuels Bioprod Biorefin 10:316-334. https://doi.org/10.1002/bbb.1641

Wild R, Patil S, Popovi M, Zappi M, Dufreche S, Bajpai R (2010) Lipids from Lipomyces starkeyi. Wild 48:329-335

Xu J, Liu N, Qiao K, Vogg S, Stephanopoulos G (2017) Application of metabolic controls for the maximization of lipid production in semicontinuous fermentation. Proc Natl Acad Sci 114:E5308 E5316. https://doi.org/10.1073/pnas.1703321114

Xue F, Zhang X, Luo H, Tan T (2006) A new method for preparing raw material for biodiesel production. Process Biochem 41:1699-1702. https://doi.org/10.1016/j.procbio.2006.03.002

Xue F, Miao J, Zhang X, Luo H, Tan T (2008) Studies on lipid production by Rhodotorula glutinis fermentation using monosodium glutamate wastewater as culture medium. Bioresour Technol 99:5923-5927. https://doi.org/10.1016/j.biortech.2007.04.046

Xue F, Miao J, Zhang X, Tan T (2010) A new strategy for lipid production by mix cultivation of Spirulina platensis and Rhodotorula glutinis. Appl Biochem Biotechnol 160:498-503. https://doi.org/10.1007/ s12010-008-8376-Z

Yang J, Xu M, Zhang X, Hu Q, Sommerfeld M, Chen Y (2011) Life-cycle analysis on biodiesel production from microalgae: water footprint and nutrients balance. Bioresour Technol 102:159-165. https://doi. org/10.1016/j.biortech.2010.07.017

Yang F, Hanna MA, Sun R (2012) Value-added uses for crude glycerol-a byproduct of biodiesel production. Biotechnol Biofuels 5:13. https:// doi.org/10.1186/1754-6834-5-13

Yang X, Jin G, Gong Z, Shen H, Bai F, Zhao ZK (2014a) Recycling biodiesel-derived glycerol by the oleaginous yeast Rhodosporidium toruloides Y4 through the two-stage lipid production process. Biochem Eng J 91:86-91. https://doi.org/10.1016/j.bej.2014.07.015

Yang X, Jin G, Gong Z, Shen H, Song Y, Bai F, Zhao ZK (2014b) Simultaneous utilization of glucose and mannose from spent yeast cell mass for lipid production by Lipomyces starkeyi. Bioresour Technol 158:383-387. https://doi.org/10.1016/j.biortech.2014.02.121
Yen H-W, Yang Y-C, Yu Y-H (2012) Using crude glycerol and thin stillage for the production of microbial lipids through the cultivation of Rhodotorula glutinis. J Biosci Bioeng xx. https://doi.org/10.1016/ j.jbiosc.2012.04.022

Ykema A, Verbree EC, Kater MM, Smit H (1988) Optimization of lipid production in the oleaginous yeast Apiotrichum curvature in whey permeate. Growth (Lakeland) 211-218

Yong-Hong LI, Bo LIU, Zong-bao Z, Feng-wu BAI, Li Y, Liu B, Zhao Z, Bai $F$ (2006) Optimization of culture conditions for lipid production by Rhodosporidium toruloides. Chin J Biotechnol 22:650-656. https://doi.org/10.1016/S1872-2075(06)60050-2

Yousuf A, Sannino F, Addorisio V, Pirozzi D (2010) Microbial conversion of olive oil mill wastewaters into lipids suitable for biodiesel production. J Agric Food Chem 58:8630-8635. https://doi.org/10. 1021/jf101282t

Yu X, Dong T, Zheng Y, Miao C, Chen S (2015) Investigations on cell disruption of oleaginous microorganisms: hydrochloric acid digestion is an effective method for lipid extraction. Eur $\mathrm{J}$ Lipid Sci Technol 117:730-737. https://doi.org/10.1002/ejlt. 201400195

Zhang J, Fang X, Zhu X-L, Li Y, Xu H-P, Zhao B-F, Chen L, Zhang X-D (2011) Microbial lipid production by the oleaginous yeast Cryptococcus curvatus $\mathrm{O} 3$ grown in fed-batch culture. Biomass Bioenergy 35:1906-1911. https://doi.org/10.1016/j.biombioe. 2011.01.024

Zhang C, Garrison TF, Madbouly SA, Kessler MR (2017) Recent advances in vegetable oil-based polymers and their composites. Prog Polym Sci 71:91-143. https://doi.org/10.1016/J. PROGPOLYMSCI.2016.12.009

Zhao X, Kong X, Hua Y, Feng B, Zhao Z(K) (2008) Medium optimization for lipid production through co-fermentation of glucose and xylose by the oleaginous yeast Lipomyces starkeyi. Eur J Lipid Sci Technol 110:405-412. https://doi.org/10.1002/ejlt.200700224

Zhao X, Wu S, Hu C, Wang Q, Hua Y, Zhao ZK (2010) Lipid production from Jerusalem artichoke by Rhodosporidium toruloides Y4. J Ind Microbiol Biotechnol 37:581-585. https://doi.org/10.1007/s10295010-0704-y

Zhou W, Wang W, Li Y, Zhang Y (2013) Lipid production by Rhodosporidium toruloides Y2 in bioethanol wastewater and evaluation of biomass energetic yield. Bioresour Technol 127:435-440. https://doi.org/10.1016/j.biortech.2012.09.067

Zhou W, Gong Z, Zhang L, Liu Y, Yan J, Zhao M (2017) Feasibility of lipid production from waste paper by the oleaginous yeast Cryptococcus curvatus. BioResources 12:5249-5263. https://doi. org/10.15376/biores.12.3.5249-5263

Zhu LY, Zong MH, Wu H (2008) Efficient lipid production with Trichosporon fermentans and its use for biodiesel preparation. Bioresour Technol 99:7881-7885. https://doi.org/10.1016/j. biortech.2008.02.033

Publisher's note Springer Nature remains neutral with regard to jurisdictional claims in published maps and institutional affiliations. 